\title{
Effect of Mulching Techniques and Irrigation Levels on Onion (Allium cepa L.) Growth Parameters Under Drip Irrigation System During Dry Season of Western Ethiopia
}

\author{
Tasisa Temesgen Tolossa ${ }^{1, a, *}$

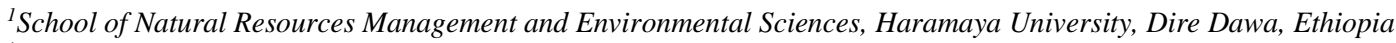
${ }^{*}$ Corresponding author

A R T I C L E I N F O A B S T R A C T

Research Article

The increasing scarcity and competition for irrigation water entails adoption of innovative practices that increase efficient water use. The objective of this research was to compare different mulching techniques and investigated the combined effect of irrigation levels under drip irrigation system based on the parametric evaluation system in western part of Ethiopia during the 2018 dry season. A factorial combination of five levels of water (namely $100 \%, 80 \%$ and $70 \%, 60 \%$ and $50 \%$ ETc) combined with three mulch treatments (namely, Normal Mulch (NM), Straw Mulch (SM) and Plastic Mulch (PM)) with three replications. The analysis of variance showed that, days to 50\% maturity, leaf number per plant, mean leaf length, plant height and leaf area were significantly affected by the main effects of deficit irrigation levels and mulching materials. The interaction effects of deficit irrigation levels and mulching materials significantly influenced plant height, number of leaf per plant, plant height, Leaf length and Leaf area of the onion. The present study suggests that, in water scarce area, farmers are advised to adopt deficit irrigation level with $80 \%$ ETc under plastic mulch. It is important even to undertake similar studies at different seasons with different varieties in consideration of their cost benefit analysis. However, if water is not a limiting factor, farmers are advised to apply full irrigation water application under plastic mulch.

Keywords:
Onion crop
Deficit irrigation
Drip irrigation
Mulching material
Growth parameter

tasisatemesgen@gmail.com

(iD) https://orcid.org/0000-0001-8937-636X

(c) (1) () To

\section{Introduction}

The expansion of irrigated agriculture to feed the ever increasing population on one hand and the increasing competition for water due to the development of other water use sectors on the other hand, as well as increasing concerns for environment, necessitated the improvement of water use efficiencies in irrigated agriculture to ensure sustained production and conservation of this limited resources (Ali, 2010).

Measures have been sought to produce more food with less water by increasing water productivity through effective development (adaptation) of genotypes and development of new water management technologies in arid and semi-arid regions for better utilization of the limited water resource (Montazar, 2009).

In the context of improving water productivity, there is growing interest in deficit irrigation, a practice where by water supply is reduced below maximum level and mild stress is allowed with minimum effect on yield. Regulated deficit irrigation is water saving technology that is relatively inexpensive and easy to implement (Webber et al., 2006 and Temesgen, 2018). Under conditions of water stress and drought, deficit irrigation can lead to greater water use efficiency by maximizing yield per unit of water used.

One way of conserving soil moisture is through application of mulch to the soil. Mulches can be used to conserve moisture and increase growth. In order to maximize water use efficiency by the plant and to improve the quality of produce, the use of mulch has become an important cultural practice in many regions of the world. The use of mulches has aided growers in increasing crop production efficiency by promoting favourable moisture and temperature conditions. The microclimate surrounding the plant and soil is significantly affected by mulch.

Therefore, a better understanding of the uses of mulching techniques and levels of irrigation in onion production is very important in order to increasing moisture and returns to the producers by physically 
increasing quality of onion. Thus, an experiment was therefore set up to investigate the influence of different mulches and irrigation levels on onion growth parameters under drip irrigation.

\section{Materials and Methods}

\section{Description of the Study Area}

The experiment was carried at Ambo agricultural Research Center, West Shoa Zone in Oromia Regional State (Figure 1).

The soil type of the area is clay with sand, silt and clay in proportion of $15 \%, 17 \%$ and $68 \%$ respectively (AARC, 2016). Major crop cultivation includes high land maize (Zea mays L.), teff (Eragrostis tef), common bean (Phasaleus vulgaris), potato (Solanum tuberosum L.), onion (Allium cepa L.) and tomato (Solanum lycopersicum). Four seasons established data based on weather and climatic conditions of the area were used to define the seasons as dry season (December to February), spring (March to May), summer (June to August) and Autumn (September to November). Farmers grow crops twice a year, one during the dry season (December to February); by using Huluka and Taltale River that flows close to the area and regularly summer season, they use rainfall.

\section{Experimental Design and Treatments}

The experimental design was a split plot design in RCBD with three replications in which deficit irrigation application levels was used as main plots and mulching techniques as sub-plots. Treatments include four deficit irrigation applications (80\% ETc, 70\% ETc, 60\% ETc and $50 \%$ ETc) and a control irrigation application (100\% ETC) and three mulching materials (no mulch (NM), straw mulch (SM) and plastic mulch (PM). Under adequate water supply (i.e., full irrigation), the crop water requirement is fully met.i'e actual evapotranspiration and maximum evapotranspiration is equal. No water stress develops under such conditions, and crop actual yield ( $\mathrm{Ya}$ ) is expected to be potential yield $(\mathrm{Ym})$, i.e. $\mathrm{Ya}=\mathrm{Ym}$ (if other production factors are not limiting). However, under limited water supply (i.e., water stress or water deficit): The level of soil water status within the plant root zone is less than what would be under full irrigation. Crop water consumption in this case (ETa) falls below maximum evapotranspiration (ETm), under such conditions, water stress will develop in the plant, which will adversely affect crop growth, that means, $\mathrm{Ya}<\mathrm{Ym}$.

\section{Experimental Procedures}

Land preparation and nursery management

The field for nursery bed was ploughed and harrowed to bring it to a fine tilth and a seed bed was prepared. Adama onion cultivar called onion from Ambo Agricultural Research Centre was used for the study. The seeds of this cultivar were sown on nursery bed and after sowing; the beds were covered with dry grass mulch until emergence and watered using a watering can. A week before transplanting, water supply to the nursery seed bed was reduced in order to harden the seedlings to reduce transplanting shock. Before transplanting, the seedlings were watered to enhance easy uprooting and to prevent root damage.

Preparation of the experimental plots

The experimental field plot was ploughed using tractor, leveled and made ready by dividing the field in to 45 plots for transplanting. The plot size was $3.5 \mathrm{~m} \times 3.9 \mathrm{~m}=13.65 \mathrm{~m}^{2}$, with $1 \mathrm{~m}$ spacing between adjacent plot and $1.5 \mathrm{~m}$ between replications. A plot consisted of five rows with a row length of $3.9 \mathrm{~m}$.
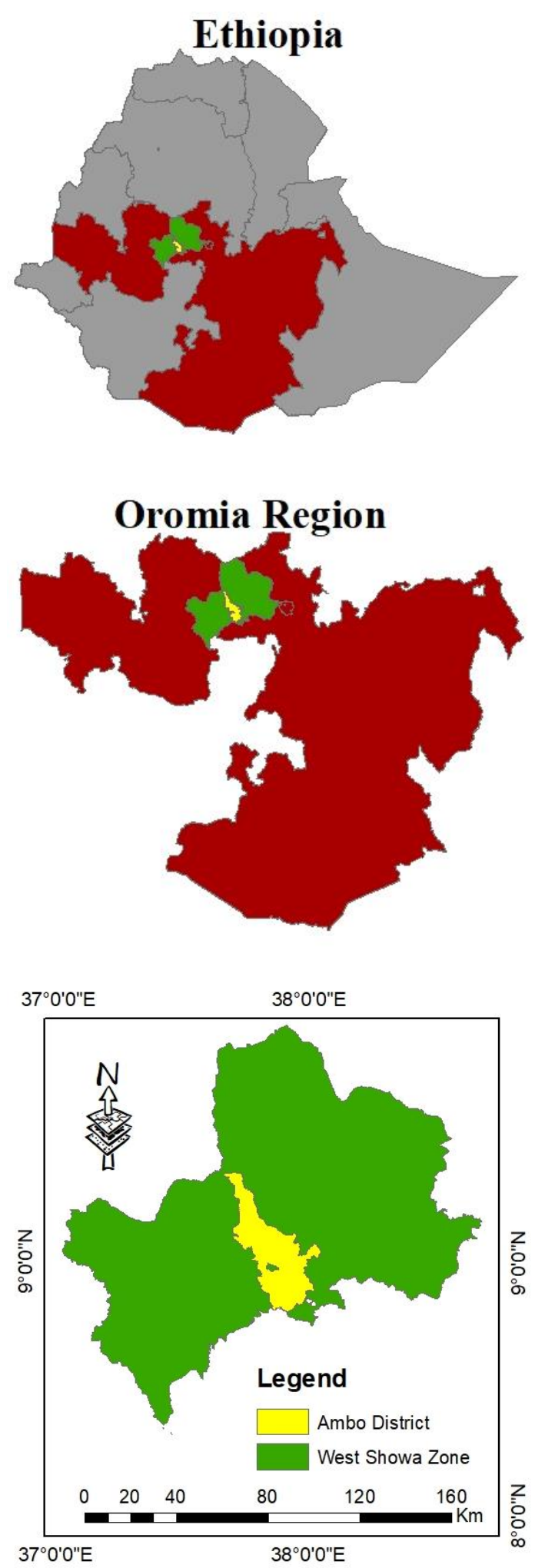

Figure 1. Map of study area 
The seedlings were transplanted to field plots on the first week of April 2017. Transplanting was done late in the afternoon to reduce the risk of poor establishment. More number of seedlings than that required for transplanting was raised so that vigorous, strong and healthy ones were selected. The spacing between plants within a row and between rows was $30 \mathrm{~cm}$ and $70 \mathrm{~cm}$ respectively, with a total of 5 rows per plot. A row consists of 13 plants and a plot 65 plants. The net harvesting areas of a plot were $3.3 \mathrm{~m}$ by $2.1 \mathrm{~m}\left(6.93 \mathrm{~m}^{2}\right)$. The first plant was planted $15 \mathrm{~cm}$ from the border row in each plot.

\section{Transplanting of Seedlings}

Uniform, healthy and vigorous seedlings (standard seedlings) of onion variety having a height of $20-25 \mathrm{~cm}$ (EARO, 2004) were transplanted (after about 6 to 7 weeks in the nursery) into the experimental field on beds at the specified spacing in the designated plots.

Table 1. Treatment groupings

\begin{tabular}{c|ccc}
\hline \multirow{2}{*}{ Deficit irrigation (DI) } & \multicolumn{3}{c}{ Mulching Materials (M) } \\
\cline { 2 - 4 } & No mulch $(\mathrm{M} 1)$ & Straw mulch $(\mathrm{M} 2)$ & Plastic mulch $(\mathrm{M} 3)$ \\
\hline $100 \%$ ETc $(\mathrm{ETa}=\mathrm{ETm} \& \mathrm{Ya}=\mathrm{Ym})$ & 1 & 2 & 3 \\
$80 \%$ ETc $(\mathrm{ETa}<\mathrm{ETm} \& \mathrm{Ya}<\mathrm{Ym})$ & 4 & 5 & 9 \\
$70 \%$ ETc $(\mathrm{ETa}<\mathrm{ETm} \& \mathrm{Ya}<\mathrm{Ym})$ & 7 & 11 & 12 \\
$60 \%$ ETc $(\mathrm{ETa}<\mathrm{ETm} \& \mathrm{Ya}<\mathrm{Ym})$ & 10 & 14 & 15 \\
$50 \%$ ETc $(\mathrm{ETa}<\mathrm{ETm} \& \mathrm{Ya}<\mathrm{Ym})$ & 13 & 14 \\
\hline
\end{tabular}

\section{Application of mulches}

Two types of mulching materials, namely plastic and straw mulch were used for the experiment. Plastic mulches were applied before transplanting of Adama onion seedlings by making small holes at the desired intra row spacing and the seedlings were transplanted. White (transparent) plastic film that allows sunlight to pass through in to the soil and having typical characteristics of 20-25 microns or 80-100 gauge thick wide was used and the area of the plots were considered in plastic mulch. Transparent plastic mulch was selected because it provides more yields than black plastic mulch and it is characterized by occurrence of higher soil temperature that it permits early germination, flowering, increases water use efficiency and harvesting than black plastic mulch. However, straw mulches were applied immediately after transplanting of seedlings. For the straw mulches dried vetivar grass (Vetiveria zizanioides L.) which is a perennial grass of Poaceae family, originated from India and Africa continent (Xia et al., 1998) was used. The dried vetiver grass which is easily available in the area was chopped to about $10-15 \mathrm{~cm}$ before it was used as mulch. Generally, mulching practice was made as 6 ton/ha for straw mulch and total area of the plots was covered with straw mulch for those plots treated with straw mulch.

Drip irrigation system installation

Drip irrigation system was used for applying irrigation water. Drip system consists of Polyvinyl Chloride main lines, sub main and laterals. The plots were levelled manually to create uniform plots within the given treatment. The drip laterals were installed in such a way that the spacing between rows is equal to that between the lateral and spacing between plants is equal to emitters spacing. There were 45 plots laid out in $3.9 \mathrm{~m}$ length, five laterals per plot. Hence, each plot consisted of five drip lateral lines; each lateral has $3.9 \mathrm{~m}$ length with 13 emitters, so that each emitter drops water to a single plant. The water from the source was collected in a water tanker of 2000 litters capacity which was placed at a height of $2 \mathrm{~m}$ above the ground surface to supply the required irrigation water to a block of experimental field. The water distribution system components (main line) were laid and connected to the water container and to the individual drip lines. The drip lines (laterals) of $12 \mathrm{~mm}$ diameter were unrolled and laid along the crop rows and each lateral served one row of crop. The end of the laterals and the main lines were closed with end cups to avoid direct soil contact and thus prevent clogging.

\section{Data Collection and Analysis}

\section{Climatic data}

Data on daily climate of the site was collected from the Ambo Agro-meteorological Observatory. The reference evapotranspiration (ETo) was computed using Penman Monteith method, Cropwat ver. 8.0 window based computer model from the climatic data gathered from AARC. The onion crop evapotranspiration (ETc) for each day was computed by multiplying the ETo by the crop coefficient $(\mathrm{Kc})$ values obtained from FAO (1977) for each of the four stages of onion, initial, development, mid and late seasons. The Kc values represented the ratio of crop evapotranspiration (ETc) and reference evaporation (ETo) rate each day. The effective rainfall was computed by the Cropwat program from the monthly total rainfall. The net daily irrigation water requirement was computed by reducing the ETc by the daily effective rainfall. The gross water requirement was computed by applying field application efficiency.

Soil sampling and analysis

Soil samples were collected from the experimental field and soil physical and chemical properties were analyzed.

Data collection and analysis

The Crop data was collected from the middle rows in order to avoid border effect. Ten plants were taken randomly and tagged from middle rows of each experimental plot for recording and observation of growth and yield parameters. The plants were picked at random carefully from middle three rows by avoiding one plant from starting and ending of three middle rows. Data regarding different components of growth yield and yield components were recorded. For each measured response data variables of analysis of variance (ANOVA) were computed. Data were analysed for variability using the statistical package SAS version 9. Mean separation were done using the Least Significance Difference (LSD) method at $1 \%$ and $5 \%$ level of probability. 


\section{Phenology and Growth Parameters}

Days to onion bulb enlargement

Was recorded as the actual number of days from the date of transplanting to the time when $50 \%$ of leave plants in each plot showed at change leave colour.

Days to onion bulb harvestable

Was recorded as the onion bulb reached at harvestable and all leaves become dried.

Plant height

This was taken from a sample of ten randomly selected onion plants marked within each plot. When the plant reaches at maturity stage, a carpenter's tape was used for measuring the height from the ground level to the top-most leaf. The mean from the ten plants was then determined.

\section{Leaf length $(\mathrm{cm})$}

Was taken from a sample of ten randomly selected onion plants marked within each plot. When the plant reaches at maturity stage, a carpenter's tape was used for measuring the leaf length from the onion stem to the top-most leaf. The mean from the ten plants was then determined.

Leaf diameter $(\mathrm{cm})$

The diameter of leaves at three different places of the leaves was measured from ten randomly selected plants using veneer calliper.

\section{Leaf area}

The leaf area was determined by the non- destructive length $\mathrm{x}$ width method using the relation: Leaf area of onion $=0.837$ (length $x$ width) (Juan et al., 2013). Ten leaves were measured with a ruler for each plot and the leaf area was determined.

\section{Number of leaf per plant}

The number of leaves in ten plants from each plot was counted after they had been dried and shelled and was divided by the number of ears to determine the mean.

\section{Statistical Analysis}

All necessary data collected were managed properly using SAS computer package version 8.2. When the treatments effect was found significant, mean difference was tested using LSD test at $\mathrm{P}=0.05$

\section{Results and Discussion}

\section{Climate Characteristics of the Ambo Area}

The pattern of the seasonality of rain at Ambo area is determined by analysing mean monthly rainfall ratio with that of rainfall module as rainfall amount. This rainfall amount used to utilize the availability of water to determine the amount and frequency of irrigation. Maximum total rainfall of the study area occurs from May to September with its peak in the months of July and August. The remaining months receive less rainfall (Table 2).

\section{Irrigation water Requirement}

The water requirement of onion was computed for the growing season using the CROPWAT 8 computer program with climate, soil and crop input data from the study area. The crop water requirement (ETc) of onion was calculated using crop coefficient approach on the basis of meeting evapotranspiration rate of a disease free crop growing in the large field under optimal soil conditions including sufficient water, fertility and achieving full production potential under the given growing environment. Analysis of monthly reference evapotranspiration (ETo) calculated from historical records of 20-years shows that the minimum reference evapotranspiration (ETo) is 2.80 $\mathrm{mm}$ /day which occurs in July and August and maximum ETo occurs from October to May (Table 2).

The net irrigation requirement was calculated using the Cropwat 8 Computer program during the total growing season is presented in Table 3 .

\section{Soil of the Experimental Site}

\section{Soil bulk density and water retention}

Irrigation scheduling is directly related to the physical properties of soil. The study area is dominated with clay soil. Clay texture soils are the opposite of sand soil and only allow water to enter them very slowly; however, they hold a large amount of water. Thus, the physical properties of a soil control both the rate at which water be applied and the total amount of water to be applied (Ali, 2010). The results of field capacity, permanent wilting point, bulk density, and total available water described in Table 4.

Table 2. 1996-2016 Monthly Average Climatic Data and ETo (Grass)* at study area

\begin{tabular}{|c|c|c|c|c|c|c|c|c|}
\hline \multirow{2}{*}{\multicolumn{2}{|c|}{$\begin{array}{c}\text { Month } \\
\text { Rain fall (mm) }\end{array}$}} & \multicolumn{3}{|c|}{ Temperature $\left({ }^{\circ} \mathrm{C}\right)$} & \multirow{3}{*}{$\begin{array}{c}\begin{array}{l}\mathrm{RH} \\
(\%)\end{array} \\
59\end{array}$} & \multirow{2}{*}{$\begin{array}{c}\text { Wind speed } \\
(\mathrm{km} / \mathrm{hr})\end{array}$} & \multirow{2}{*}{ Sunshine (hrs) } & \multirow{2}{*}{ ETo $(\mathrm{mm})$} \\
\hline & & Min. & Max. & Mean & & & & \\
\hline Jan. & 17 & 9.3 & 26.9 & 18.1 & & 2.9 & 8.2 & 3.5 \\
\hline Feb. & 10 & 10.3 & 28.2 & 19.3 & 48 & 3.1 & 8.5 & 3.6 \\
\hline Mar. & 67 & 11.5 & 29.1 & 20.3 & 50 & 3.4 & 7.2 & 3.62 \\
\hline Apr. & 62 & 11.5 & 28.2 & 19.9 & 54 & 3.2 & 6.8 & 3.52 \\
\hline May. & 104 & 11.2 & 28 & 19.6 & 60 & 3 & 6.5 & 3.5 \\
\hline Jun. & 165 & 11.2 & 25.9 & 18.6 & 68 & 2 & 5.6 & 3.2 \\
\hline Jul. & 235 & 10.8 & 24.1 & 17.5 & 80 & 1.5 & 3.9 & 2.8 \\
\hline Aug. & 205 & 10.5 & 23.5 & 17.0 & 81 & 1.2 & 3.5 & 2.8 \\
\hline Sep. & 104 & 11.2 & 24.6 & 17.9 & 74 & 1.1 & 4.6 & 3.0 \\
\hline Oct. & 39 & 9.3 & 25.8 & 17.6 & 64 & 2.1 & 8.3 & 3.6 \\
\hline Nov. & 18.7 & 8.9 & 26 & 17.5 & 59 & 2.4 & 8.6 & 3.3 \\
\hline Dec. & 10 & 8.7 & 26.1 & 17.4 & 60 & 3.7 & 8 & 3.21 \\
\hline Total & 1036 & & & & & & & \\
\hline Mean & 86.3 & 10.4 & 26.4 & 18.4 & 63 & 3.2 & 6.6 & 3.3 \\
\hline
\end{tabular}


Table 3. Crop water requirement and irrigation levels of onion

\begin{tabular}{l|cccc}
\hline \multicolumn{1}{c|}{ Water parameter } & January & February & March & April \\
\hline Calculated ETo (mm/day) & 3.6 & 3.6 & 3.62 & 3.52 \\
Kc per Month & 0.7 & 0.8 & 1.1 & 0.62 \\
Monthly ETc (mm/day) & 2.52 & 2.88 & 3.98 & 2.18 \\
100\% ETc (mm/day) & 6.35 & 8.29 & 15.85 & 4.76 \\
$80 \%$ ETc (mm/day) & 5.08 & 6.64 & 12.68 & 3.81 \\
$70 \%$ ETc (mm/day) & 4.45 & 5.81 & 11.09 & 3.33 \\
$60 \%$ ETc (mm/day) & 3.81 & 4.98 & 9.51 & 2.85 \\
$50 \%$ ETc (mm/day) & 3.18 & 4.15 & 7.92 & 2.38 \\
\hline
\end{tabular}

Table 4. Soil bulk density, water content (at FC and PWP) and total available water.

\begin{tabular}{c|cccc}
\hline Soil depth $(\mathrm{cm})$ & BD $\left(\mathrm{g} \mathrm{cm}^{-3}\right)$ & FC $(\%)$ & PWP $(\%)$ & TAW $\left(\mathrm{mm} \mathrm{m}^{-1}\right)$ \\
\hline $0-20$ & 1.09 & 40.45 & 21.53 & 206.23 \\
$20-40$ & 1.12 & 35.63 & 17.73 & 200.48 \\
$40-60$ & 1.13 & 29.73 & 17.70 & 135.94 \\
Average & 1.11 & 35.27 & 19.0 & 177.34 \\
\hline
\end{tabular}

$\mathrm{BD}=$ Bulk density, $\mathrm{FC}=$ Feld capacity, $\mathrm{PWP}=$ Permanent wilting point, $\mathrm{TAW}=$ Total available water

Table 5. Soil chemical properties at the experimental site.

\begin{tabular}{c|cccccc}
\hline Soil depth $(\mathrm{cm})$ & $\mathrm{pH}$ & $\mathrm{ECe}(\mathrm{dS} / \mathrm{m})$ & $\mathrm{OM}(\%)$ & Available P(ppm) & Available K(ppm) & Total N $(\%)$ \\
\hline $0-20$ & 7.83 & 0.21 & 3.66 & 5.9 & 285.00 & 0.13 \\
$20-40$ & 8.13 & 0.18 & 2.09 & 4.3 & 245.00 & 0.10 \\
$40-60$ & 8.01 & 0.18 & 2.06 & 3.6 & 226.00 & 0.07 \\
Average & 7.99 & 0.19 & 2.60 & 4.6 & 252.00 & 0.30 \\
Total & & & & & & 0 \\
\hline
\end{tabular}

Ece=Electoral conductivity, $\mathrm{OM}=$ Organic Matter, $\mathrm{P}=$ Phosphorous, $\mathrm{K}=$ Potassium, N=Nitrogen

Table 6. Main effect of irrigation levels and mulching techniques on days to $50 \%$ maturity of onion

\begin{tabular}{l|l|lc}
\hline \multicolumn{2}{c|}{ Irrigation level } & \multicolumn{2}{c}{ Mulching } \\
\hline $1.0 \mathrm{ETc}$ & $134.1^{\mathrm{a}}$ & $\mathrm{NM}$ & $130.2^{\mathrm{a}}$ \\
$0.8 \mathrm{ETc}$ & $131.8^{\mathrm{b}}$ & $\mathrm{SM}$ & $129.8^{\mathrm{b}}$ \\
$0.7 \mathrm{ETc}$ & $129.8^{\mathrm{c}}$ & PM & $128.8^{\mathrm{c}}$ \\
$0.6 \mathrm{ETc}$ & $127.4^{\mathrm{d}}$ & & \\
$0.5 \mathrm{ETc}$ & $124.9^{\mathrm{e}}$ & & \\
\hline
\end{tabular}

F-test **, CV (\%) 1.60, Means in the columns followed by the same letter(s) are not significantly different from each other at $5 \%$ level of significance, LSD $(0.05)=$ Least significant difference at $5 \%$ and CV $(\%)=$ coefficient of variation.

The bulk density of the soil of the study area showed variation with depths. It varied between 1.09 to $1.13 \mathrm{~g} / \mathrm{cm}^{3}$, with several increase in the depths (Table. 4). The top 0-20 $\mathrm{cm}$ has an average bulk density of $1.11 \mathrm{~g} / \mathrm{cm}^{3}$, whereas the sub surface layers (20-40 and 40-60 cm) have bulk density values of 1.12 and $1.13 \mathrm{~g} / \mathrm{cm}^{3}$, respectively. High bulk density is an indicator of low soil porosity and soil compaction. It may cause restrictions to root growth and poor movement of air and water through the soil. Compaction can result in shallow plant rooting and poor plant growth, influencing crop yield and reducing vegetative cover available to protect soil from erosion.

As shown in the table the result of soil moisture content at field capacity varied with the depth between $40.45 \%$ at surface $(0-20 \mathrm{~cm})$ and (at $40-60 \mathrm{~cm})$ soil depth. The moisture content at permanent wilting point was higher at surface $0-20 \mathrm{~cm}$ and decrease with depth to 17.7 at depth of $40-60 \mathrm{~cm}$.

Total available water (TAW) which is the amount of water that a crop can extract from its root zone is directly related to variation in field capacity and permanent wilting point. In result of study area, high value of TAW was found in top soil, whereas lower values were recorded, in study area in the subsurface soil. Average value of TAW at top $0-20 \mathrm{~cm}$ was $206.23 \mathrm{~mm} / \mathrm{m}$, whereas $200.48 \mathrm{~mm} / \mathrm{m}$ and $135.94 \mathrm{~mm} / \mathrm{m}$ at depths of $20-40 \mathrm{~cm}$ and $40-60 \mathrm{~cm}$, respectively.

\section{Soil Chemical Properties at the Experimental Site}

In addition to physical properties, soils have unique chemical properties as well. The main chemical properties of soil are $\mathrm{pH}, \mathrm{ECe}$, salinity, Available Phosphorous, Available Potassium, carbon to nitrogen ratio ( $\mathrm{C} / \mathrm{N}$ ratio). The soil $\mathrm{pH}$ of the study area varied with depth (Table 5). It was relatively higher at sub surface than the surface soil indicating, that the soil is tend to be alkaline (Jones, 2003).

According to Fikire and Olani (2010), onion plant can grow from neutral to slightly alkaline condition. The experimental site therefore had a favourable soil $\mathrm{pH}$ for onion growth. The ECe of the soil, which ranged from 0.21 at a depth of $0-20 \mathrm{~cm}$ to 0.175 at lower depths, indicates that the soil is non-saline and non-sodic. According to Ecocrop (2003), crops not tolerate saline above (>4dS/m). This indicates that soil salinity of the experimental site was very low with negligible effect on the crop. 
As indicated in the above table, the organic matter content of the soil had average values of $2.6 \%$. The average organic matter content of the soil, determined by WalkleyBlack method, was found to be $2.6 \%$ (1.724 OC). The highest value of OM was recorded in the top layer. This might be due to the highest crop residue in the soil for the top layer, compared to the subsurface layers. Similarly, the average value of available $\mathrm{P}$, available $\mathrm{K}$ and total $\mathrm{N}$ contents of the soil were $4.6 \mathrm{ppm}, 252 \mathrm{ppm}$, and $0.1 \%$, respectively. By depending reference of Neerraja et al. (1999) who reported that application of nitrogen fertilizer at the rate of $150 \mathrm{~kg}$ ha- 1 increased biological yield of onion, the study result are not enough for onion production

\section{Phenology and Growth Parameters of Onion}

\section{Day of $50 \%$ bulb maturity}

The number of days to $50 \%$ maturity showed highly significant $(\mathrm{P}<0.01)$ difference in response to the main effect of deficit irrigation levels and mulching materials. However, deficit irrigation levels and mulching materials did not interact to influence this parameter (Table 6). The treatment that received full irrigation required the longest time (115 days) to mature than other treatments while the treatment that received $50 \%$ ETc required the shortest time (93 days) to mature (Table 6). The length of days to $50 \%$ maturity became longer as the amount of water application increased. These results indicated the effect of full application in prolonging the phenological periods of onion as observed in the treatment that received $100 \%$ ETc. This could be due to promoted vegetative growth and prolonged transition to maturity period. This finding disagrees with Gonzalez et al. (2007) who reported that; water deficit did not hasten ripening but reduced biomass production of onion. However, the result is in agreement with the finding of Sezen et al. (2006) who reported that the total length of growing season of onion was 115 days after transplanting under different drip irrigation regimes. The finding also agrees with Adey (2006) and Habtie (2007) who reported that, the length of days to maturity of Tomato became longer as the frequency and amount of water application increased.

Mulching also hastened early maturity of onion. The shortest duration of days to reach maturity was recorded from plants mulched with transparent plastic mulch followed by plants mulched with straw mulch. However, onion planted without mulch took the longest days to attain maturity. The use of plastic mulch is effective to hasten early maturity because it promotes plant growth that leads to early days to maturity of plant. Goreta et al. (2005) reported that application of polyethylene films as mulch have shortened the growing season and enhanced early maturity in watermelon.

Plant height

The analysis of variance showed that highly significant $(\mathrm{P}<0.01)$ differences were observed due to the interaction effect of deficit irrigation levels and mulching materials (Table 7). The highest plant height $(75.07 \mathrm{~cm})$ was recorded from the combined application of $100 \%$ ETc and plastic mulch. On the other hand, the shortest plant height $(45.80 \mathrm{~cm})$ was recorded from the combined application of $50 \%$ ETc and no mulch. For each mulching material, plant height decreased with increase in irrigation deficit levels (Table 7). From this finding it is clearly seen that as the deficit irrigation level increased the plant height decreased.

Table 7. Interaction effect of irrigation levels and mulching techniques on plant height of onion

\begin{tabular}{l|cccccc}
\hline & \multicolumn{5}{c}{ Mulching Irrigation level } \\
\cline { 2 - 7 } & $100 \%$ ETc & $80 \%$ ETc & $70 \%$ ETc & $60 \%$ ETc & $50 \%$ ETc & Mean \\
\hline PM & $75.07^{\mathrm{a}}$ & $69.07^{\mathrm{cd}}$ & $65.47^{\mathrm{e}}$ & $62.07^{\mathrm{g}}$ & $53.80^{\mathrm{j}}$ & 65.1 \\
SM & $72.80^{\mathrm{b}}$ & $68.07^{\mathrm{d}}$ & $64.73^{\mathrm{ef}}$ & $59.00^{\mathrm{h}}$ & $50.87^{\mathrm{k}}$ & 63.1 \\
NM & $70.67^{\mathrm{c}}$ & $67.13^{\mathrm{de}}$ & $63.40^{\mathrm{fg}}$ & $57.00^{\mathrm{i}}$ & $45.80^{1}$ & 60.8 \\
Mean & 72.85 & 68.09 & 64.53 & 59.36 & 50.16 & \\
\hline
\end{tabular}

LSD (0.05) 2.49, F-test **, CV (\%) 1.90, Means in the columns followed by the same letter(s) are not significantly different from each other at $5 \%$ level of significance, $\operatorname{LSD}(0.05)=$ Least significant difference at $5 \%$; and $\mathrm{CV}(\%)=$ coefficient of variation.

Table 8. Interaction effect of irrigation levels and mulching techniques on number of Leaf per plant of onion

\begin{tabular}{l|cccccc}
\hline & \multicolumn{5}{|c}{ Mulching techniques and Irrigation levels } \\
\cline { 2 - 7 } & $100 \%$ ETc & $80 \%$ ETc & $70 \%$ ETc & $60 \%$ ETc & $50 \%$ ETc & Mean \\
\hline PM & $21.73^{\mathrm{a}}$ & $18.67^{\mathrm{bc}}$ & $17.00^{\mathrm{de}}$ & $14.53^{\mathrm{g}}$ & $12.67^{\mathrm{ij}}$ & 16.92 \\
SM & $19.67^{\mathrm{b}}$ & $18.40^{\mathrm{bcd}}$ & $16.80^{\mathrm{ef}}$ & $14.27^{\mathrm{gh}}$ & $12.00^{\mathrm{jk}}$ & 16.23 \\
NM & $19.60^{\mathrm{b}}$ & $17.80^{\text {cde }}$ & $16.00^{\mathrm{f}}$ & $13.43^{\mathrm{hi}}$ & $11.13^{\mathrm{k}}$ & 15.59 \\
Mean & 20.33 & 18.29 & 16.60 & 14.08 & 11.93 & \\
\hline
\end{tabular}

LSD (0.05) 0.772 F-test * CV (\%) 1.90, Means in the columns followed by the same letter(s) are not significantly different from each other at 5\% level of significance, $\operatorname{LSD}(0.05)=$ Least significant difference at $5 \%$; and CV $(\%)=$ coefficient of variation

Table 9. Main effects of irrigation levels and mulching techniques on leaf area $\left(\mathrm{cm}^{2}\right)$

\begin{tabular}{c|c|cc}
\hline \multicolumn{2}{c|}{ Irrigation level } & \multicolumn{2}{c}{ Mulching } \\
\hline $1.0 \mathrm{ETc}$ & $111.42^{\mathrm{a}}$ & $\mathrm{PM}$ & $103.52^{\mathrm{a}}$ \\
$0.8 \mathrm{ETc}$ & $108.40^{\mathrm{a}}$ & $\mathrm{SM}$ & $63^{\mathrm{b}}$ \\
$0.7 \mathrm{ETc}$ & $83.40^{\mathrm{c}}$ & $\mathrm{NM}$ & \\
$0.6 \mathrm{ETc}$ & $66.00^{\mathrm{d}}$ & & \\
$0.5 \mathrm{ETc}$ & $62.3 \mathrm{~d}$ & & LSD (0.05) 1.90 \\
\hline
\end{tabular}

F-test * CV (\%) 1.20, Means in the columns followed by the same letter(s) are not significantly different from each other at 5\% level of significance, $\operatorname{LSD}(0.05)=$ Least significant difference at $5 \%$; and CV $(\%)=$ coefficient of variation. 
The increase in plant height with increases irrigation water could be mainly due to better availability of soil moisture that has enhancing effects on the vegetative growth of plants by increasing cell division and elongation. The increasing plant height with adequate depth of irrigation application also indicate the favourable effect of water in maintaining the turgor pressure of the cell which is the major prerequisite for growth (Ramada and Raman than, 2017). On the contrary, shortening of plant height under soil moisture stress may be due to stomata closure and reduced $\mathrm{CO}_{2}$ and nutrient uptake by the plants and hence, photosynthesis and other biochemical process hampered, affecting plant growth (El-Noemani et al., 2009).

This finding is in agreement with the findings of Aklilu (2009) and Takele (2009) who reported that, plant height of onion decreased with decreased irrigation level. This result is also supported by Sezen et al. (2005) who reported similar results that the height of onion at harvest under different irrigation regimes varied from 43 to $51 \mathrm{~cm}$. However, the reduced plant height at $50 \%$ ETc treatments may be attributed to the effects of water stress on cell expansion.

Mulching technics significantly increased plant height. For each deficit irrigation level, higher plant height was recorded from plots treated with plastic mulch followed by plots treated with straw mulch (Table 7). This might be due to the availability of moisture since mulching conserves moisture than un mulched plots. These findings are in accordance with that of Ahmad et al. (2011) who found that the use of transparent plastic mulch was increased the plant height in chilli than straw mulch and control.

\section{Number of leaf per plant}

In general, the tallest plants tended to have more number of Leaves per plant which was partly due to the increased growing points in taller plants. This result is supported by the finding of Tekele (2009) who reported that decreased irrigation level from full irrigation, decreased the number of primary and secondary Leaf of onion per plant at I50 and I75 irrigation treatments.

Mulching was significantly enhanced number of Leaf per plant. For each deficit irrigation level, highest numbers of Leaf per plant were recorded from plots treated with plastic mulch than straw and no mulch. Furthermore, straw mulch also proved significantly better than the no mulch in increasing the number of Leaf per plant. The lowest numbers of Leaf were counted from the treatment planted without mulching. The present result is in agreement with the findings of Chawla (2006) who reported the highest number of Leaf (18.54 per plant) at harvest in marigold with application of plastic mulch compared to other mulching treatment and control (Table 8).

\section{Leaf area}

Leaf surface area decreases as the amount of water applied to the crop also decreases. Differences in the total leaf area per plant (LAPP) observed among different levels of irrigation water application.

There was highly significant difference among treatments in total leaf area per plant. Among the applied irrigation levels, $100 \%$ ETc gave significantly the higher leaf area than those treatments received 80, 70,60 and 50\% ETc. The highest leaf area was recorded from plant grown under $100 \%$ ETc while the minimum leaf area was recorded from plants grown under 50\% ETc (Table 9). From this finding it can be observed that increase in the deficit irrigation level from $100 \%$ ETc to $50 \%$ ETc resulted in a reduction of leaf area (Table 9).

Those treatments by $20 \%$ deficit at specific stage had a higher leaf area compared to $50 \%$ deficit at specific stage. However, the stressed ones got one fourth of the required amount of irrigation water throughout the growing season have a narrow and small leaf in order to conserve the amount of water lost through transpiration. Similar findings have also reported by Bagali (2012) that the plant water stress also retards leaf area expansion and reduced leaf area, which is more important for decrease in crop growth.

On the other hand, mulching was greatly effective in increasing the leaf area. The plastic mulch significantly enhanced leaf area over straw and no mulch. Further, straw mulch also proved significantly better than the no mulch in increasing the leaf area. The lowest leaf areas were counted from the treatment planted without mulching. Accordingly, the maximum leaf areas were recorded from plastic mulch followed by straw mulch. The minimum leaf areas were recorded from un mulched treatments.

\section{Conclusion and Recommendation}

Water scarcity remains the major limiting factor in intensifying agricultural production especially, in where shortage of water is the major constraint to stabilize crop production. Efficient use of irrigation water using appropriate irrigation systems and management is an important consideration in the drought prone season of the region for improved crop production.

One way of conserving soil moisture is through application of mulch techniques and drip irrigation to the soil. Mulches can be used to conserve moisture and increase growth. In order to maximize water use efficiency by the plant and to improve the quality of produce, the use of mulch has become an important cultural practice in many regions of the world.

The results of the experiment revealed that days to $50 \%$ maturity, growth parameters were significantly affected $(\mathrm{P}<0.01)$ by the main effects of deficit irrigation levels and mulching materials but deficit irrigation levels and mulching materials did not interact to influence these parameters. This indicates that recommendation of deficit irrigation and mulching should be done separately for each parameter. However, the interaction effects of deficit irrigation levels and mulching materials significantly influenced plant height, number area, number of leaf per plant.

Based on the overall findings obtained from this research and observations, the following recommendations are made: the findings of this research suggested that, farmers are advised to apply optimal irrigation water application under plastic mulch when water is not a limiting factor. However, when irrigation water is a limiting factor near small holder's farm, farmers are advised to practice $80 \%$ ETc irrigation with plastic mulch throughout the growth stages of onion. In this study, however, different amount of irrigation water was applied throughout the growing period under different mulch covers in one season and one place. Therefore, further 
works should be done by applying different amount of deficit irrigation levels and mulching techniques at different growth stages of the crop and repeating the experiment will improve the validity of findings in order to develop proper deficit irrigation scheduling and reach at sound conclusions and recommendations. The drip system technology used in the study is at entry level for farmers and it is aptly demonstrated from this work that the amount of water savings that can be achieved is substantial when compared to other irrigation systems. In arid and semi-arid areas where water supply is scarce, conducting research on deficit irrigation with different drought tolerant crops is more preferable than full irrigation and most drought susceptible crops.

\section{References}

AARC (Ambo Agricultural Research Center). 2016. Ambo Agricultural Research Center Profile Ethiopian, Agricultural Research Institute. Addis Ababa, Ethiopia.

Adey Nigatu. 2006. Water use and yield response of drip-irrigated tomato to soil water depletion and mulching. M.Sc Thesis, Haramaya University, Haramaya, Ethiopia.

Ahmad I, Hussain Z, Raza S, Memon N. and Naqvi SA. 2011. Response of Vegetative and Reproductive Components of Chilli to Inorganic and Organic Mulches. Pakistan Journal of Agricultural Sciences, 48(1): 19-24.

Aklilu Masfin. 2009. Effect of mulching and depth of irrigation application on water use efficiency and productivity of pepper under gravity drip irrigation. MSc Thesis, Haramaya University, Haramaya, Ethiopia.

Ali MH. 2010. Fundamentals of Irrigation and On-farm Water Management. Springer Science and Business Media, New York USA. pp.583.

Bagali AN. 2012. Effect of scheduling of drip irrigation on growth, yield and water use efficiency of onion (Allium cepa L.). Indian Karnataka. Journal of Agriculture Science, 25(1):116-119.

Chawla SL. 2006. Effect of irrigation regimes and mulching on vegetative growth, quality and yield of flowers of African marigold. Ph.D. Thesis, Department of Horticulture, Maharana Pratap University of Agriculture and Technology, Udaipur.India.

EARO (Ethiopian Agricultural Research Organization). 2004. Released crop varieties and their recommended cultural practices. Progress report. Addis Ababa, Ethiopia.

Ecocrop K. 2003. Plant Production and Protection Information System (online).

El-Noemani AA, Aboamera AA, Dewedar OM. 2009. Growth, yield, quality and water use efficiency of pea plant as affected by evapotranspiration and sprinkler height. Journal of Agricultural Research, 34: 1445-1466.
Fikire M, Olani N. 2010. Onion Seed Production Techniques Manual for Extension Agents and Seed Producers. Asella, Ethiopia.

Gonzalez VD, Orgaz F, Federes E. 2007. Response of pepper to deficit irrigation for paprika production. Journal of Horticultural Science 114: 77- 82.

Goreta S, Perica S, Dumicic G, Bucan L, Zanic K. 2005. Growth and yield of watermelon on polyethylene mulch with different spacings and nitrogen rates. Journal of Horticultural Science, 40: 366-369.

Habtie H. 2007. Comparison of different Irrigation Scheduling Methods for Tomato (Lycopersicum esculentum L.) Production in Libokemkem Woreda south Gondar Zone. MSc Thesis, Haramaya University, Haramaya, Ethiopia.

Jones JB. 2003. Agronomic Handbook: Management of crops, Soils, and Their Fertility CRC Press LLC, Boca Raton, Florida, United State of America.

Juan I, Co'rcoles K, Jose F, David H, Miguel A, Moreno A. 2013. Estimation of leaf area index in onion (Allium cepa L.) using an unmanned aerial vehicle. Journal of Bio system Engineering, 115:31-42

Montazar A. 2009. Assessing the global water productivity of some irrigation command areas in Iran. World Academy of Science, Engineering and Technology, 150: 18-29.

Neeraja GK, Reddy IP, Reddy YN. 1999. Effect of irrigation and nitrogen on growth, yield and yield attributes of onion (Allium cepa L.) in Andhra Pradesh. Journal of Vegetable Science, 26(1): 64-68.

Ramada S, Ramanathan SP. 2017. Evaluation of Drip Fertigation in Aerobic Rice-onion Cropping System. International Journal of Current Microbiology and Applied Sciences, 6(4): 2623-2628.

Sezen SM, Yazar A, Eker S. 2005. Effect of drip irrigation regimes on yield and quality of field grown bell pepper. Agricultural Water Management, 81: 115-131.

Sezen SM, Yazar A and Eker S. 2006. Effect of drip irrigation regimes on yield and quality of field grown bell pepper. Agricultural. Water Management, 81: 115-131.

Tekele G. 2009. Effects of drip irrigation levels and planting methods on yield and water use efficiency of pepper in Bako, Western Oromia. MSc Thesis, Haramaya University, Haramaya, Ethiopia.

Temesgen T. 2018. Irrigation Level Management and Mulching on onion (Allium cepa L.) Yield and WUE in Western Ethiopia. The Journal of the Science of Food and Agriculture, 2(3): 45-56.

Webber HA, Madramootoo CA, Bourgault M, Horst MG, Stulina G, Smith DL. 2006. Water use efficiency of common bean and green gram grown using alternate furrow and deficit irrigation. Agricultural Water Management. 86: 259-268.

Xia HP, Ao HX, Hen DQ. 1998. Effect of vetiver grass in soil amelioration, and water and soil conservation. In: L.Y. Xu (eds.). Vetiver research and development. Science and Technology press of China Agriculture,101-106p 